Fifth International Conference on Sustainable Construction Materials and

Technologies. http://www.claisse.info/Proceedings.htm

\title{
EFFECTS ON FLEXURAL STRENGTH OF CONCRETE BEAMS USING WASTE POLYTHENE BAGS AS PARTIAL FINE AGGREGATE REPLACEMENT
}

\author{
Richie. I. Umasabor \\ Civil Engineering Department, University of Benin
}

Email: umasabor.richie@uniben.edu,princerich247@yahoo.co.uk, Phone no: 08062486118

\begin{abstract}
The study examines the effect of shredded polythene bags when used as a partial replacement of fine aggregate on the flexural strength of concrete beams. The experiment carried out produced thirty six (36) samples of blended concrete beams of size $100 \mathrm{~mm} \times 100 \mathrm{~mm} \times 50 \mathrm{~mm}$, when the shredded polythene bags were partial replaced at $5 \%$ and $10 \%$ weighted ratios for fine aggregate in concrete.

The results show that the average flexural strength for grade 20 concrete increases as the percentages of shredded polythene bags increase while that of grade 30 flexural strength decrease as the dosage of shredded polythene bags increases. The average flexural strength for $5 \%$ and $10 \%$ fine aggregate replacement using grade 20 concrete was $5.0625 \mathrm{~N} / \mathrm{mm}^{2}$ and $5.2980 \mathrm{~N} / \mathrm{mm}^{2}$ which are $9.04 \%$ and $14.1 \%$ increases over the control concrete at 28 days. It is concluded that grade 20 concrete performs better than grade 30 concrete.
\end{abstract}

Keywords: Flexural strength, shredded polythene bags, fine aggregate, concrete beams

\subsection{INTRODUCTION}

Flexural strength which is also called the Modulus of Rupture (MR) or Bending Strength as a term which refers to the material property, defined as the stress in a material just before it yields in a flexure test. It represents the highest stress experienced within the material at its moment of yield (Hodgkinson, 2000).

Flexural strength or modulus of rupture (MR) is about $10-20 \%$ of the compressive strength depending on the type, size and volume of coarse aggregate used. However, the best correlation for specific materials is obtained by laboratory tests for given materials and concrete mix design. The standard test methods are ASTM C 78 (2018) (third-point loading) or ASTM C 293 (2016) (center-point loading). The MR determined by third-point loading is usually lower than the MR determined by the center-point loading, sometimes by as much as 15\% (NRMCA, 2000).

Researchers lately have become interested in using waste polythene bags in concrete. A research conducted by Mahesh et al. (2016) studied the strengthening of concrete by 
the percentage replacement of fine aggregate with recycled waste plastic (polyethylene) in the concrete, which was used to produce one hundred and twenty six samples of concrete. The compressive, splitting tensile and flexural strength were examined at 7 days to 28 days and the fine aggregate was replaced with $1 \%, 3 \%$ and $5 \%$ of recycled waste plastic in the concrete. The results show that when waste plastic bottles increased from $0 \%$ to $5 \%$ of the sand in the mix, the compressive and splitting tensile strength of concrete decreased by the ratios of $12.8 \%$ and $10.71 \%$ while the flexural strength increased by $4.1 \%$ respectively at 7 days test and also the compressive, splitting tensile and flexural strength decreased by the ratios of $7.93 \%, 28.6 \%$, and $23.6 \%$ at 28 days test respectively.

The study carried out by Rahmani et al. (2013) evaluated the effects of replacing 5\%, $10 \%$ and $15 \%$ substitution of sand with Polyethylene Terephthalate (PET) processed particles. The results show an initial increase of flexural strength at early age of curing when the amount of PET particles increases, but it drops after a while. There was an increase in flexural strength of $6.71 \%$ and $8.02 \%$ at $5 \%$ replacement of sand volume with PET particles using w/c ratios of 0.42 and 0.54 . However, a reduction of flexural strength of $14.75 \%$ and $6.25 / \%$ occurred, when $15 \%$ substitution of PET particles was used at w/c ratio of 0.42 and 0.54 .

A research work by Ogunfayo et al. (2015) evaluated the properties of concrete with fine aggregates being replaced with granulated plastic waste [GPW] using high density polyethylene (HDPE). The fine aggregate was substituted from 0\% to 50\% (with $0 \%$ serving as the control) and water-cement ratio ranges from $0.6-0.7$ using a concrete mix of $1: 2: 4$.

Results showed that at 7 days curing period, the compressive strength of $21.42 \mathrm{~N} / \mathrm{mm}^{2}$, $17 \mathrm{~N} / \mathrm{mm}^{2}$ and $9.67 \mathrm{~N} / \mathrm{mm}^{2}$ for $10 \%, 20 \%$ and $30 \%$ fine aggregate replacement was achieved while the control was $21.75 \mathrm{~N} / \mathrm{mm}^{2}$ at 28 days. It was recommended that a $10 \%$ replacement be used for structural works while $20 \%$ and $30 \%$ should be used for light weight concrete. The above literatures have shown that waste polythene bags can be successfully used in concrete. Its usage depends on the purposes the concrete is to be used for.

It is now well known that the amount of plastic waste that we generate is exorbitant enough to warrant a global crisis. The large deposition of waste polymer materials is as a result of increase in industrialization all over the world. The increase in the global annual production of plastic materials is about five million tons in the 1950s and grew to three hundred and forty eight (348) million tons in 2017 (Plastic-the Facts, 2018). Old plastic furniture, different household plastic materials, equipment, anti-static packaging materials are termed plastic waste materials (Manhal and Farah, 2016).

Besides that, the global economic recession forced materials price increased, consequently the cost of constructions, including the cost for coarse aggregate (Hadipramana et al., 2016). Hence, to overcome this problem, the ordinary constituent material must be superseded by the low-cost material to cut the expense construction. The re-use of waste polythene bags for replacing ordinary fine and coarse aggregate concrete is one way to solve that problem. The waste polythene bag is a non-degradable 
material which may cause huge environmental problems. It is a welcome development if an attempt is made, to channel the waste polythene bags to constructive purposes (Hadipramana et al., 2016).

A need for cheap, new standard materials that will greatly reduce the density of normal concrete and with the availability of large plastic, and polythene waste just lying idle, a source to provide solution to this must also be explored. The plastic does not corrode; it is lighter than steel fibers and a better control of shrinkage cracking in concrete (Shanmugapriya and Helen, 2017).

In this work, an attempt is made to study the effects of the partial replacement of fine aggregate (sand) with a new material ( waste polythene bags) on the flexural strength of concrete beams using samples tested for 7 days, 14 days and 28 days of curing.

\subsection{MATERIALS AND METHOD}

The materials used consist of shredded polythene bags, Portland cement, crushed coarse aggregate of $20 \mathrm{~mm}$ size, fine aggregate and water. The tools used included beam moulds (100mm x 100mm x 500mm size), shovel, head pans and concrete mixer. The $100 \mathrm{~mm} \times 100 \mathrm{~mm} \times 500 \mathrm{~mm}$ beam moulds were used. University of Benin (UNIBEN) sachet water polythene bags were obtained in University of Benin, Ugbowo campus, Benin City, Nigeria.

The preparation of the shredded polythene bags was carried out by hand, using a sharp scissor to produce nylon bits of both regular and irregular shapes. These shapes ranged from lengths of $0.2 \mathrm{~cm}$ to $1.35 \mathrm{~cm}$ on their longest side (particle analysis by observation and span lengths by ruler measurement). These shapes ranged from lengths of $0.2 \mathrm{~cm}$ to $1.35 \mathrm{~cm}$ on their longest side (particle analysis by observation and span lengths by ruler measurement). Total percentage of regular shapes was $27 \%$ and for the irregular shapes was $73 \%$. The percentage distribution of the longest side lengths is given thus: $0.2-0.5 \mathrm{~cm}-6 \%, 0.5-0.75 \mathrm{~cm}-14 \%, 0.75-1 \mathrm{~cm}-65 \%$ and $1-1.35 \mathrm{~cm}-15 \%$. Total percentage of regular shapes was $27 \%$ and for the irregular shapes was $73 \%$.

The weighted percentages of shredded polythene bags (SPB) of 5\% and 10\% dosage of fine aggregate in concrete grade 20 and grade 30 were used in the concrete production while control concrete contains $0 \%$ (SPB). The number of specimen produced for the experiments were thirty six (36) concrete specimen of size $100 \mathrm{~mm} \mathrm{x}$ $100 \mathrm{~mm} \times 500 \mathrm{~mm}$ concrete beams.

The concrete beams were cast according to the minimum standard of BS 1881-102: 1983 for concrete making. After curing the specimen for 7 days, 14 days and 28 days they were tested using the simple beam, third point flexural test method, to obtain their various flexural strengths according to ASTM C78 (2018) methodology. Data were obtained from experimental tests conducted which included sieve analysis and flexural strength test.

\subsection{RESULTS AND DISCUSSION}




\subsubsection{Sieve Analysis}

ASTM C136 (2014) method were used in carrying out the sieve analysis. The result, shown in Figure 1 falls within zone 3 which is suitable for manufacturing of concrete.

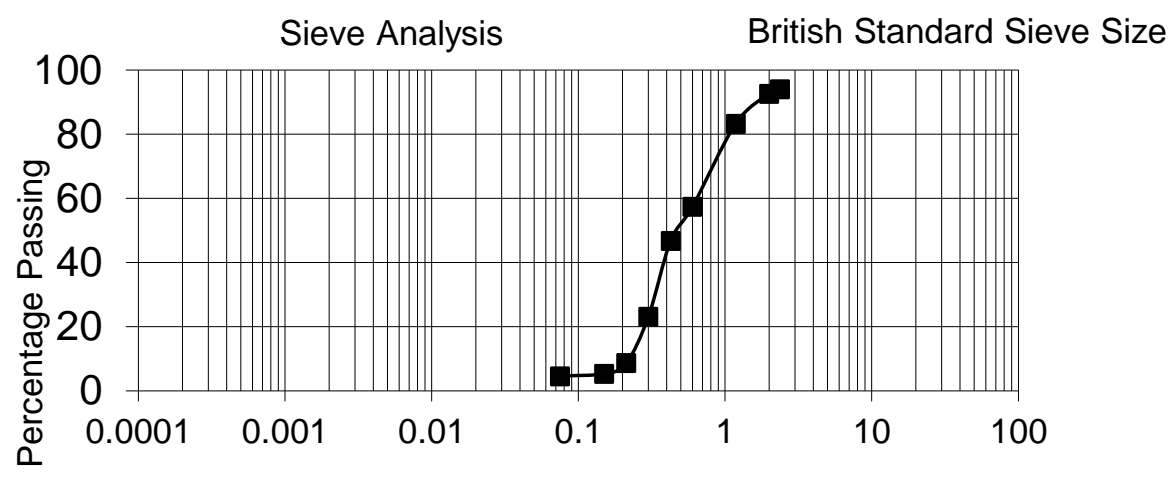

Fig.1.0: Sieve analysis for fine aggregate

\subsubsection{Flexural Strength Test}

The flexural strength test of the concrete beams followed the standard procedures stated in ASTM C78 (2018) methodology. The flexural strength of the shredded polythene bags concrete beams increased at 7 days and 28 days curing period from $0 \%$ to $10 \%$ for concrete grade 20 and decreases for concrete grade 30 between 7 days and 28 days of curing period as shown in Table 1 and Table 2 respectively.

Table 1: The flexural strength of blended concrete beams using grade 20 concrete

\begin{tabular}{|l|l|l|l|}
\hline $\begin{array}{l}\text { Days of } \\
\text { Curing }\end{array}$ & \multicolumn{3}{|l}{$\begin{array}{l}\text { Average flexural strength of } \\
\text { the blended concrete beams } \\
\left(\mathrm{N} / \mathrm{mm}^{2}\right)\end{array}$} \\
\cline { 2 - 4 } & $0 \%$ SPB & $5 \%$ SPB & $\begin{array}{l}10 \% \\
\text { SPB }\end{array}$ \\
\hline 7 & 2.8860 & 2.9445 & 3.6765 \\
\hline 14 & 3.53310 & 4.7145 & 3.8550 \\
\hline 28 & 4.6425 & 5.0625 & 5.2980 \\
\hline
\end{tabular}

Table 2: The flexural strength of blended concrete beams using grade 30 concrete

\begin{tabular}{|l|l|l|l|}
\hline $\begin{array}{l}\text { Days of } \\
\text { Curing }\end{array}$ & $\begin{array}{l}\text { Average flexural strength of } \\
\text { the blended concrete beams } \\
\left(\mathrm{N} / \mathrm{mm}^{2}\right)\end{array}$ \\
\cline { 2 - 4 } & $0 \%$ SPB & $5 \%$ SPB & $\begin{array}{l}10 \% \\
\text { SPB }\end{array}$ \\
\hline 7 & 2.4150 & 2.4750 & 2.4750 \\
\hline 14 & 4.8600 & 8.3070 & 3.1260 \\
\hline 28 & 5.8710 & 5.7015 & 5.4840 \\
\hline
\end{tabular}




\subsection{DISCUSSION}

\subsubsection{Flexural Strength of SPB Concrete Beams made with Grade 20 Design Mix}

Figure 2.0 show that the flexural strength of the shredded polythene bag (SPB) concrete beams increased from 7 days to 28 days curing period between $0 \%$ and $10 \%$ replacement with fine aggregate for grade 20 concrete. The 7 days blended concrete beams, percentages increase of the flexural strength at 5\% and 10\% fine aggregate replacement are $2.03 \%$ and $27.4 \%$ for grade concrete 20 . While the 28 days blended concrete beam, flexural strength percentages increase are $9.04 \%$ and $14.1 \%$ for $5 \%$ and $10 \%$ fine aggregate replacement. This may be due to the shredded polythene bags acting as fibre reinforcement in the blended concrete. This behaviour was collaborated by Mahal and Farah, (2016). The load deflection curve of the concrete beams containing the shredded polythene bags showed the arrest of the propagation of micro cracks which agreed with the study of Ismail and Al-Hashmi, (2007).

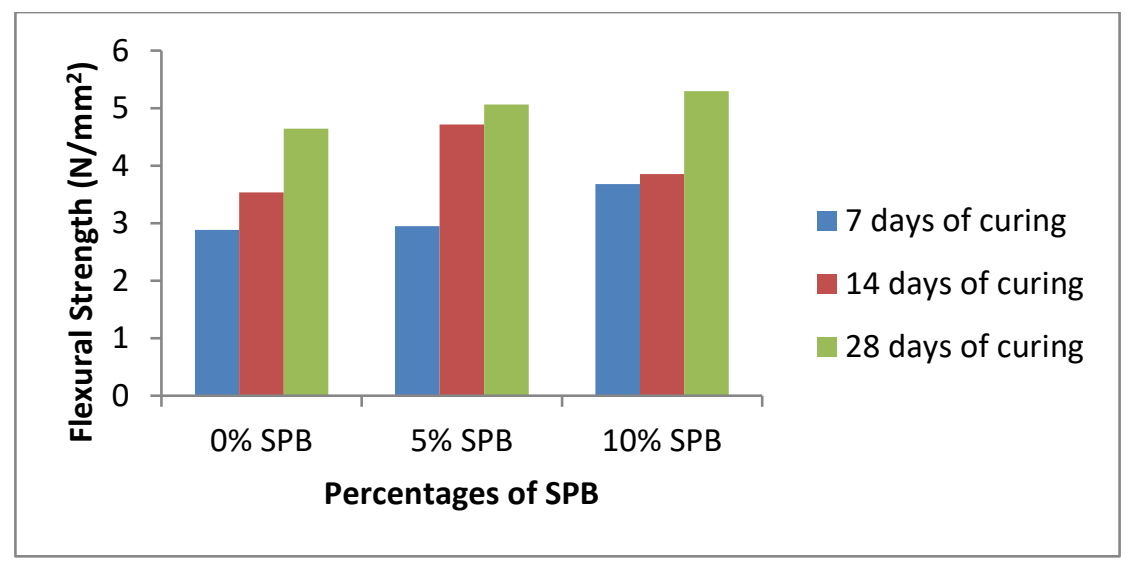

Fig.2.0: Flexural strength of blended concrete beams with \% SPB dosage at various curing period for grade 20 concrete.

\subsubsection{Flexural Strength of SPB Concrete Beams made with Grade 30 Design Mix}

There was an early flexural strength increase at 7 days for 5\% and 10\% dosage with a marginal increase of $2.48 \%$ when compared to the control concrete as shown in Figure 3.0. This behaviour was observed by Dharmaraj and Iyappan (2016) and Rahmani et al., (2013). 


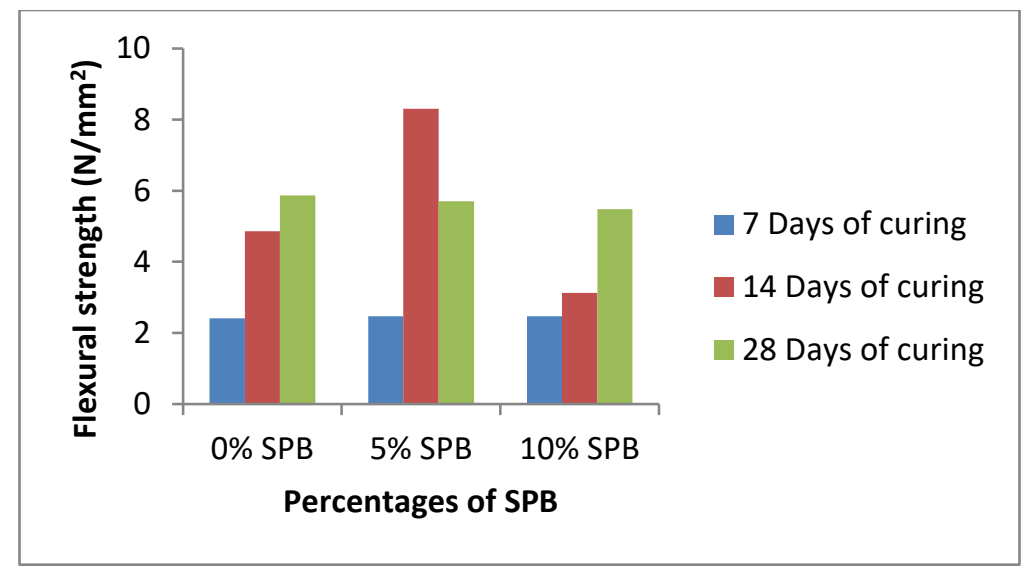

Fig.3.0: Flexural strength of blended concrete beams with \% SPB dosage at various curing period for grade 30 concrete.

However, flexural strength of the shredded polythene bags (SPB) concrete beams for 28 days curing duration decreased by $97.1 \%$ and $93.4 \%$ at $5 \%$ and $10 \%$ dosage when compared to the control concrete as shown in Figure 3.0. This trend may be due to the polythene bags not having proper bonding with cement paste which was collaborated by Amalu et al., (2016).

\subsection{CONCLUSION}

Based on the findings, the following can be concluded as thus:

1. Shredded polythene bags can be used to replace fine aggregate in concrete up to $10 \%$ replacement using grade 20 concrete.

2. The grade 20 concrete mix design performs better in shredded polythene bag replacement than grade 30-mix design concrete.

3. The optimum flexural strength of the blended concrete was $5.2980 \mathrm{~N} / \mathrm{mm}^{2}$ at 28 days of curing for grade 20 concrete, which was $14.1 \%$ increase over the control concrete.

4. Grade 30 mix design concrete was not suitable for the blended concrete due to the progressive decrease in flexural strength of the blended concrete beams at $5 \%$ and $10 \%$ fine aggregate replacement with shredded polythene bags.

5. There will be huge economic savings and reduction in environmental pollution when $10 \%$ of the shredded polythene bags are used in concrete.

6. The load-deflection curve of concrete containing the shredded polythene bags showed the arrest of micro cracks, which may be applicable in areas where high toughness is required. 


\subsection{REFERENCES}

Amalu, R.G; Azeef .A; Muhammad .H; Rejith, K.U. and Vijitha, V. (2016) " Use of Waste Plastic as Fine Aggregate Substitute in Concrete". International Journal of Scientific and Engineering Research, Vol.7, Issue 4, pp.172177

ASTM C78 (2018), "Standard Test Method for Flexural Strength of Concrete (Using Simple Beam with Third-Point Loading)", ASTM International, West Conshohocken, PA, 2018, https://doi.org/10.1520/c0078 c0078m-18

ASTM C293 (2016), "Standard Test Method for Flexural Strength of Concrete (Using Simple Beam With Center-Point Loading)", ASTM International, West Conshohockenhttps://doi.org/10.1520/c0293

ASTM C136 (2014) Standard Test Method for Sieve Analysis of Fine and Coarse Aggregates, ASTM International, WestConshohocken https://doi.org/10.1520/c0136

BS 1881, Part 102 (1983) - Testing Method for the Determination of Slump. British Standards Institute, London. United Kingdom. https://doi.org/10.3403/00048831u

Dharmaraj, R. and Iyappan, G. (2016) " Suitability of Partial Replacement of Purverized Plastics as Fine Aggregate in Cement Concrete" Indian Journal of Science and Technology, Vol.9, No.23, pp.1-6. https://doi.org/10.17485/ijst/2016/v9i23/95856

Hadipramana, .J; Mokhatar, S. N; Samad, A. A. A. and Hakim, N. F. A. (2016). "An Exploratory Compressive Strength of Concrete Containing Modified Artificial Polyethylene Aggregate (MAPEA)", International Engineering Research and Innovation Symposium (IRIS), (IOP Conf. Ser.: Mater. Sci. Eng. 160 012065). $\quad$ https://doi.org/10.1088/1757-899x/160/1/012065

Hodgkinson, J. M. (Ed.). (2000). Mechanical Testing of Advanced Fibre Composites". Elsevier https://doi.org/10.1201/9781439822791

Manhal, A. J. and Farah, P. (2016). "Strength and Behavior of Concrete Contains Waste Plastic", Journal of Ecosystem \&Ecography, https://doi.org/10.4172/2157-7625.1000186

Mahesh, .M; Rao, V. N. and Satya, S. H. (2016). "Re-Use of Polyethylene Plastic Waste in Concrete", International Journal of Engineering Development and Research, Vol. 4, Issue 4.

National Ready Mix Concrete Association (NRMCA, 2000). "Flexural Strength of Concrete", Silver Spring MD 20910. 
Ogunfayo, I. K; Soyemi, O. B and Sanni, A. O. (2015)." Flexural Properties of Finely Granulated Plastic Waste as a Partial Replacement of Fine Aggregate in Concrete", International Journal of Engineering Sciences, Vol. 4, No. 5, pp. 65-68.

Plastics-The Facts (2018). "An Analysis of European Plastics Production, Demand and Waste Data. Plastic Europe Research Group

Rahmani, .E; Dehestani, .M; Beygi, M.H.A; Allahyari, H. and Nikbin, I.M (2013) "On the Mechanical Properties of Concrete Containing Waste PET Particles", Construction and Building Materials, Vol.47, pp.1302-1308. https://doi.org/10.1016/i.conbuildmat.2013.06.041

Shanmugapriya, M. and Helen, S. M. (2017). "Strength and Chloride Permeable Properties of Concrete with High Density Polyethylene Wastes", International Journal of Chemical Sciences Vol. 15.

Ismail, .Z. Z, and Al-Hashmi, E. A. (2007) "Use of Waste Plastic in Concrete Mixture as Aggregate Replacement", Department of Environmental Engineering, College of Engineering, University of Baghdad, Iraq. https://doi.org/10.1016/i.wasman.2007.08.023 